\title{
Implementasi Program IMTAQ (Iman dan Taqwa) dalam Pembentukan Akhlakul Karimah Santri Mahasiswa di Pondok Pesantren X Dago Bandung
}

\author{
Muhammad Armel Nursena*, Huriah Rachmah, Sobar Al Ghazal \\ Prodi Pendidikan Agama Islam, Fakultas Tarbiyah dan Keguruan, \\ Universitas Islam Bandung, Indonesia. \\ *armelnursena@gmail.com, huriahrachmah@unisba.ac.id, sobaralghazal01@gmail.com
}

\begin{abstract}
The morality of a child, teenager and even an adult is not getting better because it is caused by the occurrence of several cases of moral decline in society. In fact, during the IMTAQ program at the X Dago Islamic Boarding School, Bandung, there were still students who skipped classes when learning started, came late at the time of learning to the mosque to pray five times a day, lazy to pray in congregation, lazy to read the Qur'an. and not showing a polite attitude or ta'dzim to teachers and people who are older than him. This study aims to determine the planning, implementation, supporting and inhibiting factors of the Imtaq Program (Faith and Taqwa) in the formation of morality for students at X Islamic Boarding School. The method used in this study is a descriptive qualitative method. The type of data used is qualitative data. In terms of collecting data, the researcher used observation, interview, and documentation studies. While the data analysis techniques used are through, reduction, data presentation, triangulation and drawing conclusions (verification). The results of this study generally indicate that the IMTAQ program, which is carried out regularly, has brought significant results to the students. These changes include cognitive, affective, and psychomotor aspects which are marked by the attitudes that appear in the students in the imtaq program, namely Tawadu 'and ta'dzim wa taqriman. However, only twenty percent of the X Islamic Boarding School students still do not have a sense of awareness in following the imtaq program rules, only some of them already have the awareness to obey the rules.
\end{abstract}

Keywords: IMTAQ Activities, Akhlakul Karimah, Students.

\begin{abstract}
Abstrak. Akhlak yang dimiliki seorang anak, remaja bahkan dewasa tidak semakin membaik karena diakibatkan oleh terjadinya beberapa kasus kemerosotan akhlak dimasyarakat. Nyatanya, pada saat Program imtaq di Pondok Pesantren X Dago Bandung, masih ada santri yang membolos ketika pembelajaran dimulai, datang terlambat pada saat pembelajaran ke masjid untuk melaksanakan solat lima waktu, malas untuk melaksanakan solat berjamaah, malas untuk membaca al- qur'an dan kurang menunjukan sikap sopan atau ta'dzim kepada guru maupun orang yang lebih tua darinya. Penelitian ini bertujuan untuk mengetahui perencanaan, pelaksanaan, faktor pendukung dan penghambat Program Imtaq (Iman dan Taqwa) dalam pembentukan akhlakul karimah santri mahasiswa di Pondok Pesantren X. Metode yang digunakan dalam penelitian ini adalah metode kualitatif bersifat deskriftif. Jenis data yang digunakan yaitu data kualitatif. Dalam hal mengumpulkan data, peneliti menggunakan teknik observasi, wawancara, dan studi dokumentasi. Sedangkan teknik analisis data yang digunakan yaitu melalui, reduksi, penyajian data, triangulasi dan penarikan kesimpulan (verifikasi). Hasil penelitian ini secara umum menunjukkan bahwa program imtaq yang dilaksanakan secara rutin tersebut, telah membawa hasil yang signifikan pada santri mahasiswa. Perubahan-perubahan tersebut menyangkup aspek kognitif, afektif, dan psikomotorik yang ditandai dengan sikap yang nampak pada santri dalam program imtaq yaitu Tawadu' dan ta'dzim wa taqriman. Akan tetapi, hanya saja dua puluh persen santri Pondok Pesantren X masih belum memiliki rasa kesadaran dalam mengikuti tata tertib program imtaq hanya sebagian yang sudah memiliki kesadaran untuk mentaati tata tertib.
\end{abstract}

Kata Kunci: Program IMTAQ, Akhlakul Karimah, Santri Mahasiswa 


\section{A. Pendahuluan}

Banyak berimbas pada dunia pendidikan pesantren yakni krisis akhlak. Permasalahan akhlak yang dimiliki seseorang tidak semakin membaik (1). Nyatanya 86 persen anak-anak, remaja hingga dewasa yang kecanduan game online, gadget, kasus pelecehan seksual, serta tersandung kasus penggunaan barang haram seperti narkoba dan pesta miras (2). Sehingga, banyaknya kasus kemerosotan akhlak yang terjadi di dalam dunia pesantren seperti contoh banyak santri yang tidak menghormati guru, kurang kesadaran dalam kebersihan sekitar maupun lingkungan, sering bolos sekolah, tawuran antara pelajar dan lain sebagainya (3). Oleh karena itu dibutuhkan lembaga pengajaran agama islam seperti pondok pesantren. Sebagai lembaga yang sangat berperan dalam pengembangan akhlak dan mental santri (4). Serta sebagai salah satu pondasi utama dalam membentuk manusia berakhlak mulia di sisi Allah SWT (5).

Muslimin di dalam penelitiannya melihat tujuan khusus pondok pesantren Manbaul Ulum dalam pembentukan akhlakul karimah yaitu mendidik santri untuk menjadi muslim dan muslimah yang bertaqwa kepada Allah, memiliki kecerdasan, dan berakhlak mulia (6). Fenomena yang terjadi dalam pembentukan akhlak santri hampir sama dengan santri di pondok pesantren lainnya. Namun, ada sebagian kecil santri yang belum berakhlakuul karimah. Sehingga para guru, orang tua dan pondok pesantren harus bahu-membahu dalam membentuk akhlakul karimah santri. (7). Banyak cara yang dapat dilakukan dalam upaya pembentukan akhlakul karimah santri. Metode-metode yang digunakan juga sangat bervariasi. Akan tetapi, tidak semua sekolah menjadikan pembentukan akhlakul karimah peserta didik menjadi tujuan utama. Karena sekolah saat ini lebih mengutamakan persaingan dari segi akademis bukan dari sisi output perilaku yang baik, apalagi sekolah yang memang bukan berbasis Islam (8).

Kondisi tersebut cocok dengan pengertian dari akhlak sendiri yaitu berasal dari kata khuluqun yang berarti budi pekerti, perangai, tingkah laku atau tabiat. Sedangkan secara istilah akhlak adalah kebiasaan atau kodrat manusia, yaitu suatu keadaan pikiran yang telah terbentuk, sehingga dalam jiwa benar-benar melekat sifat-sifat yang melahirkan perbuatan - perbuatan dengan mudah dan spontan tanpa dipikirkan dan diangan-angan lagi (9).

Allah SWT berfirman dalam surah QS. Al-A'raf: 199:

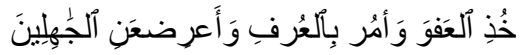

"Jadilah engkau pemaaf dan suruhlah orang mengerjakan yang ma'ruf, serta berpalinglah dari pada orang-orang yang bodoh.” (QS. Al-A'raf: 199).

Ayat ini mengandung arti yang begitu luas, dengan kalimatnya yang singkat sehingga mencakup seluruh aspek akhlakul karimah. Ibnu Maskawaih di dalam teorinya memandang bahwa akhlak ialah "hal li n nafsi daa'iyatun lahaa ila af'aaliha min ghoiri fikrin walaa ruwiyatin" yaitu sifat yang tertanam dalam jiwa seseorang yang memotivasinya untuk bekerja tanpa perlu musyawarah dan mufakat. Sedangkan menurut Abu Hamid Al Ghazali Akhlak ialah sifat yang terukir dalam jiwa seseorang, di mana lahir tindakan yang menyenangkan dan mudah dilakukan tanpa memikirkan diri sendiri, tanpa khawatir(10). Kurangnya pembentukan akhlak pada zaman sekarang ini menimbulkan ancaman untuk generasi muda di era globalisasi 4.0. Tidak sedikit masyarakat yang minim akan akhlakul karimah. Mengakibatkan banyak permasalahan yang terjadi mulai dari anak-anak, remaja bahkan kalangan dewasa.

Pondok Pesantren X selama ini mempunyai suatu program kepesantrenan seperti, pembelajaran kitab kuning, muhadhoroh, MCB (Mimkho Character Building), membaca alqur'an, sholat berjamaah, dan PHBI. Yang terkumpul dalam satu program yaitu IMTAQ (Iman dan Taqwa). Dengan adanya program IMTAQ ini diharapkan mampu membentuk dan mendidik santri-santrinya menuju generasi muda yang berakhlakul karimah.

Peneliti mengadakan penelitian ini bertolak dari hasil observasi awal di pondok pesantren X Dago Bandung, dilihat pada saat program imtaq dilaksanakan masih ada santri yang membolos ketika disaat pembelajaran dimulai, datang terlambat ketika pembelajaran dimulai ataupun ketika datang ke masjid untuk melaksanakan solat lima waktu, malas untuk melaksanakan solat berjamaah, malas untuk membaca al- qur'an dan kurang menunjukan sikap sopan atau ta'dzim kepada guru maupun orang yang lebih tua darinya. Hal ini menimbulkan kurangnya akhlak santri kepada guru pada saat proses pembelajaran, sehingga santri kurang dapat mengembangkan dan membentuk akhlak pada dirinya. 
Permasalahan-permasalahan tersebut terjadi karena minimnya Pendidikan dalam pembentukan akhlak yang mereka miliki. Maka dari itu, Penerepan dan pembentukan akhlak sangat diperlukan untuk diaplikasikan sehari-hari (11). Agar generasi muda memiliki akhlakul karimah, maka Pondok Pesantren X berusaha menerapkan pembentukan akhlak kepada santri mahasiswa melalui program imtaq, dengan tujuan untuk membentuk dan mencetak santri-santri yang mengedepankan akhlakul karimah.

Hal yang terdapat dalam penelitian Jusran dikatakan bahwa IMTAQ merupakan gabungan dari dua kata yakni kata Iman dan Taqwa yang masing-masing memiliki pengertian tersendiri (12). IMTAQ merupakan bentuk perilaku manusia terhadap tuhan dan sesama manusia. Dan dari penelitian Sita mengatakan bahwa Program Imtaq merupakan sebuah program yang ditujukan untuk mendukung tujuan Pendidikan Agama Islam, yaitu menumbuhkan dan meningkatkan keimanan seseorang menjadi insan kamil dengan pola taqwa, dapat hidup dan berkembang secara wajar dan normal karena ketaqwaannya kepada Allah SWT dan program Imtaq ditujukan untuk membentuk karakter siswa sejalan dengan prioritas pendidikan nasioanal (13).

Uraian di atas melatarbelakangi ketertarikan peneliti untuk mengadakan penelitian guna memperoleh gambaran secara jelas tentang : Implementasi Program Imtaq (Iman Dan Taqwa) Dalam Pembentukan Akhlakul Karimah Santri Mahasiswa Di Pondok Pesantren X Dago Bandung.

\section{B. Metodologi Penelitian}

Metode yang digunakan dalam penelitian ini adalah metode kualitatif bersifat deskriftif. Informan kunci adalah Pengasuh Santri Mahasiswa Dan Ustadz. Jenis data yang digunakan yaitu data kualitatif. Dalam hal mengumpulkan data, peneliti menggunakan teknik observasi, wawancara, dan studi dokumentasi. Sedangkan teknik analisis data yang digunakan yaitu melalui, reduksi, penyajian data, triangulasi dan penarikan kesimpulan (verifikasi).

\section{Hasil Penelitian dan Pembahasan}

Pondok pesantren X Membuat Perencanaan program dengan cara rapat dewan pengurus pesantren. perancangan program imtaq dibuat bersama dengan seluruh dewan guru termasuk juga para pimpinan melalui rapat musyawarah yang disepakati secara bersama-sama. Program imtaq di pondok pesantren dengan di sekolah pada prinsipnya sama akan tetapi kalau di lihat dari prospek nya itu sangat jauh berbeda. Program diunggulkan seperti pembiasaan untuk sholat berjamaah , pembiasaan sholat-sholat sunah, pembiasaan ibadah-ibadah ghoiru mahdoh dan riyadhoh. Metode yang di gunakan yaitu ceramah atau berdakwah, kedua simulasi, ketiga praktik. Kendala ketika program imtaq yaitu penyesuaian konsep program antara kesibukan kampus dan pesantren, berbedanya perguruan tinggi disetiap santri mahasiswa, sulitnya mengumpulkan para guru untuk bisa duduk dalam satu waktu, dan sulitnya menyeimbangkan antara ilmu agama dengan kemajuan zaman sekarang,

Cara guru mengatasi kendala tersebut yaitu dengan mencoba untuk di siasati seminimal mungkin mengikuti program mahasiswa di kampusnya. kebijakan dalam melaksanakan sholat berjamaah hanya tiga waktu mulai dari magrib, isya dan subuh. Sehingga sebagian santri mahasiswa ada yang mengikuti sholat berjamaah di pondok dan yang tidak mengikuti tetapi tetap melaksanakan sholat berjamaah di tempatnya masing-masing. Cara agar santrinya selalu melaksanakan sholat berjamaah yaitu dengan memotivasinya, memperingatinya, dan dengan menerapkan program-program yang melibatkan seluruh santri seperti reminder atau door to door yang di lakukan setiap kali menjelang waktunya masuk sholat. Sebagian santri ada yang sudah taat dan sebagian ada juga yang masih belum taat. Cara yang dilakukan agar santrinya taat dalam beribadah yaitu dengan memberikan dorongan agar tetap istiqomah dalam menjalankan ibadah dan juga undang-undang kesantrian.

Dalam penerapan sholat malam (qiyamul lail) sudah terprogram akan tetapi sifatnya kondisional hanya di adakan dalam acara tertentu. Cara guru agar santrinya dapat mengikuti sholat berjamaah tepat pada waktunya yaitu dengan diingatkan (memberikan reminder), motivasi, dan penjadwalan seperti melaksanakan murotal al-qur'an, pembiasaan solawat 
sebelum sholat, dan mengajak menggunakan speaker atau mic yang di sediakan. Hukuman yang setimpal bagi santri mahasiswa yang tidak mengikuti sholat berjamaah yaitu semacam punishment yang tertera dalam undang-undang kesantrian. Dalam pelaksanaan hukuman tersebut belum berjalan dengan optimal. Masih ada santri yang datang terlambat ketika pembelajaran dimulai. Santri mahasiswa yang datang terlambat ketika pembelajaran akan mendapatkan hukuman sesuai dengan tata tertib.

Cara guru mengatasi santri mahasiswa yang terlambat ketika pembelajaran berlangsung yaitu dengan diingatkan atau di biarkan dengan alasan agar santri berpikir dengan kesalahannya dan juga diberikan tugas tambahan agar santri tidak tertinggal dengan materi yang telah di pelajari. Upaya yang di lakukan agar meningkatkan kemampuan dalam membaca al-qur'an yaitu dengan program takhosus pendampingan terhadap santri yang dilaksanakan setiap ba'da magrib. Santri mahasiswa pada prinsipnya sudah ta'dzim kepada guru akan tetapi tingkatan dari ta'dzim itu masih berbeda-beda, ada yang benar-benar ta'dzim, ada yang masih memulai dan ada yang baru setengah.

Upaya guru dalam menerapkan rasa ta'dzim santri kepada yang lebih tua yaitu dengan memberikan materi-materi yang berkaitan dengan masalah etika, budi pekerti dan materi khusus yaitu kitab ta'lim muta'alim. Cara menentukan program dan tujuan program imtaq yaitu dengan musyawarah untuk mufakat dengan adanya rapat dewan pimpinan, penekanan waktu kepada santri mahasiswa, dan juga penambahan materi. Dalam mempersiapkan program imtaq yang di lakukan guru adalah persiapan terlebih dahulu, memfollowup para santrinya, dan meidentifikasi kebutuhan santri.

Cara guru menyesuaikan jam pembelajaran pondok dengan waktu kuliah yaitu dengan meniadakan program pada siang hari dan menjadikan malam hari sebagai waktu dimulainya program. Dan mentoleransi bagi semua samtrinya yang jarang mengikuti program pondok karena ada tugas ataupun program di kampusnya dengan syarat harus izin terlebih dahulu bagi santri yang meninggalkan ta'lim tiga kali dalam satu minggu maka dia akan di panggil di peringatkan atau bahkan di kembalikan haknya kepada orang tua. Program imtaq yang ada di pondok pesantren $\mathrm{X}$ sudah terprogram dengan baik akan tetapi belum sepenuhnya nya optimal atau sempurna masih dalam tahap proses penyempurnaan.

Program yang di unggulkan, yaitu ada muhadhoroh, MCB, dan riyadhoh.pelaksanaan program imtaq yang di lakukan guru adalah persiapan terlebih dahulu, memfollowup para santrinya, dan meidentifikasi kebutuhan santri.Ada tiga yang terlibat dalam pelaksanaan program imtaq di pondok pesantren $X$ yaitu pertama santri mahasiswa, kedua dewan as'atidz dan pengurus pesantren ketiga stakeholder yang ada di dalam dan di luar. hukuman atau konsekuensi kepada santrinya dengan hukuman yang secara tidak langsung seperti hukum moral dan peringatan. Akhlak santri yang telah mengikuti program imtaq pada hakikatnya pasti ada perubahan dan itu semua kembali lagi kepada diri santri masing-masing.

Adanya program imtaq imtaq dapat membentuk akhlakul karimah santri karena didalam sebuah program imtaq terdapat sebuah proses yang luar biasa di lalui oleh para santri. Program imtaq memberi pengaruh terhadap pembentukan akhlakul karimah santri karena dalam sebuah proses pembelajaran akan membentuk sebuah hasil yaitu santri yang baik yang memiliki iman yang kuat, dan amal soleh yang meningkat. Sikap yang nampak pada santri dalam program imtaq yaitu Tawadu' dan ta'dzim wa taqriman tetapi masih ada santri yang memang begitu respect beriman, cuek, dan sedikit masa bodo apatis Sebagian santri mahasiswa pondok peantren $\mathrm{X}$ sudah memiliki kesadaran untuk mentaati tata tertib. 20 persen santri pondok peantren $\mathrm{X}$ masih belum memiliki rasa kesadaran dalam mengikuti program imtaq.

Ketika program imtaq berlangsung masih ada Sebagian kecil santri mahasiswa yang tidak tepat waktu. upaya guru menghadapi santri yang telat dalam program imtaq yaitu di dekati dan diingatkan. Faktor pendukung di luar lingkungan pondok pesantren yaitu dengan mengikuti program-program yang mengarah kepada imtaq seperti mengikuti perlombaan dakwah ataupun mengikuti undangan tabligh yang diselenggarakan oleh pesantren-pesantren di luar sana. Kendala di alami di luar pondok pesantren yaitu tidak terkontrolnya perilaku santri ketika sedang berada di luar pondok peantren. Upaya untuk mengatasi kendala santri di luar lingkungan pondok yaitu dengan pengontrolan dan melakukan kerja sama antar kampus tetapi hal ini belum 
dilakukan oleh pondok pesantren $\mathrm{X}$.

Faktor pendukung di dalam pondok pesantren yaitu keluarga dan faktor pendukung dalam bentuk material yaitu sarana prasarana yang memadai. Kendala didalam lingkungan pondok yaitu berbagai macamnya santri dari latar pendidikan yang berbeda-beda dan faktor dari luar pondok yang terbawa ke dalam pondok pesantren. Upaya untuk mengatasi kendala tersebut yaitu dengan penguatan dan penambahan materi, wejangan, teori, dan pengaplikasiannya dalam kehidupan sehari-hari santri.

\section{Kesimpulan}

Berdasarkan pembahasan dalam penelitian ini, peneliti menyimpulkan beberapa hasil penelitian sebagai berikut:

1. Guru membuat perencanaan program imtaq yaitu dengan cara rapat dewan pengurus pesantren, dan merancang program imtaq bersama dengan seluruh dewan guru termasuk juga para pimpinan melalui rapat musyawarah yang disepakati secara bersama-sama. Metode yang digunakan dalam program yaitu metode ceramah atau berdakwah, simulasi, dan praktik. Adapun kendala dalam program imtaq yaitu penyesuaian konsep program antara kesibukan kampus dan pesantren, berbedanya perguruan tinggi disetiap santri mahasiswa, sulitnya mengumpulkan para guru untuk bisa duduk dalam satu waktu, dan sulitnya menyeimbangkan antara ilmu agama dengan kemajuan zaman sekarang, cara mengatasi kendala tersebut yaitu dengan mencoba untuk di siasati seminimal mungkin mengikuti program mahasiswa di kampusnya. Dalam menentukan program dan tujuan program imtaq yaitu dengan musyawarah untuk mufakat dengan adanya rapat dewan pimpinan, penekanan waktu kepada santri mahasiswa, dan juga penambahan materi.

2. Dalam proses pelaksanaan program imtaq sama halnya dengan persiapan dalam program yaitu dengan persiapan terlebih dahulu, memfollowup para santrinya, dan meidentifikasi kebutuhan santri. Ada tiga yang terlibat dalam pelaksanaan program imtaq yaitu santri mahasiswa, dewan as'atidz dan pengurus pesantren, dan stakeholder yang ada didalam maupun diluar. Hukuman atau konsekuensi yang tidak mengikuti program imtaq yaitu dengan hukuman yang secara tidak langsung seperti hukum moral dan peringatan. Maka akhlak santri yang telah mengikuti program imtaq pada hakikatnya pasti ada perubahan dan itu semua kembali lagi kepada diri santri masing-masing. Program imtaq yang dilaksanakan secara rutin tersebut, telah membawa hasil yang signifikan pada santri mahasiswa. Perubahan-perubahan tersebut menyangkup aspek kognitif, afektif, dan psikomotorik yang ditandai dengan sikap yang terlihat pada santri dalam program imtaq yaitu Tawadu' dan ta'dzim wa taqriman. Hanya saja dua puluh persen dari santri mahasiswa Pondok Pesantren X masih belum memiliki rasa kesadaran dalam mengikuti tata tertib program imtaq hanya sebagian santri yang sudah memiliki kesadaran untuk mentaati tata tertib.

3. Faktor pendukung yang di alami oleh pondok pesantren dalam pembentukan akhlakul karimah santri mahasiswa di luar lingkungan pondok pesantren yaitu dengan mengikuti program-program yang mengarah kepada imtaq. Adapun kendalanya yaitu tidak terkontrolnya perilaku santri ketika sedang berada di luar pondok pesantren Maka upaya yang dilakukan yaitu dengan pengontrolan dan melakukan kerja sama antar kampus tetapi hal ini belum dilakukan. Faktor pendukung yang di alami oleh pondok pesantren dalam pembentukan akhlakul karimah santri mahasiswa di dalam pondok pesantren itu sendiri yaitu keluarga pesantren dan faktor pendukung dalam bentuk material yaitu sarana prasarana yang memadai, kendala yang dialami oleh pondok yaitu berbagai macamnya santri dari latar pendidikan yang berbeda-beda, faktor dari luar pondok yang terbawa ke dalam pondok pesantren. Upaya untuk mengatasi kendala yang terdapat di dalam pondok yaitu dengan penguatan dan penambahan materi, wejangan, teori, dan pengaplikasiannya dalam kehidupan sehari-hari santri. 


\section{Acknowledge}

Peneliti mengucapkan terima kasih kepada seluruh pihak yang telah membantu dalam penyusunan artikel ini.

\section{Daftar Pustaka}

[1] Fadli MM. Peran Lembaga Pesantren Dalam Membentuk Akhlak Santri Di Era Modern [Internet]. Vol. 1, Kompasiana. 2021 [cited 2021 Sep 13]. p. 3. Available from: https://www.kompasiana.com/muhammad59885/613ef01131a28760f87ec212/pesantrendalam-pembentukan-akhlak-santri-sebagai-bekal-kehidupan

[2] Syarifah U. The Prospect and Challenge of Pesantren Miftahul Midad Education Practice in Modern Era. 2020;1(1).

[3] Abdul RJ, Yakin N, Emawati E. Implementasi Pendidikan Karakter Santri di Era Teknologi (Studi Pondok Pesantren Putri Nurul Hakim Kediri Lombok Barat. J SCHEMATA Pascasarj UIN Mataram. 2020;9(2):171-88.

[4] Anjarwati A. Program Studi Pendidikan Agama Islam. Vol. 5. 2018.

[5] Ratnasari A. Peran Pondok Pesantren As-Salafiyyah Mlangi Yogyakarta Dalam Pembinaan Akhlak Santriwati. Skripsi. 2014;

[6] Muslimin. Metode Pembentukan Akhlakul Karimah pada Santri di Pondok Pesantren Manbaul Ulum. J Pemikir Keislaman,. 2020;1(1):1-9.

[7] Mafruhah S, Sulistiani IR, Mustafida F. VICRATINA : Jurnal Pendidikan Islam Volume 4 Nomor 7 Tahun 2019 e-ISSN: ---- - -----. J Pendidik Islam. 2019;4:23-9.

[8] Ridwan, Wasis Ladamay, Arfa' M. Peran guru pendidikan agama islam dalam pembinaan akhlakul karimah peserta didik di sma muhammadiyah 8 cerme gresik. Jurnal TAMADDUN - FAI UMG. 2020.

[9] Badrudin. Akhlak Tasawuf. 2nd ed. Mansur S, editor. Angewandte Chemie International Edition, 6(11), 951-952. Serang: IAIB PRESS; 2015. 20oo p.

[10] Kurniawan A. Pengertian Akhlak [Internet]. GURUPENDIDIKAN.COM. 2021. Available from: https://www.gurupendidikan.co.id/pengertian-akhlak/

[11] Wijaya BA. Pendidikan Akhlak Dalam Membentuk Sikap Disiplin Santri Di Pondok Pesantren Darun Najah Ngijo Malang. J Pendidik Islam. 2019;4:23-9.

[12] Jusran. Hubungan Antara Program Jum'at Imtaq (Iman Dan Taqwa) Dengan Akhlak Peserta Didik Di Smkn 3 Kendari [Internet]. INSTITUT AGAMA ISLAM NEGERI (IAIN) KENDARI; 2017. Available from: http://digilib.iainkendari.ac.id/798/

[13] Sita DM. Penerapan Program Imtaq Dalam Menanamkan Karakter Siswa Di Smpn 23 Seluma " Program Studi Pendidikan Agama Islam Fakultas Tarbiyah Dan Tadris Institut Agama Islam Negeri ( Iain ) Bengkulu Tahun 2018. 2018. 